\title{
Estimation of Genetic Characteristics and Cumulative Power of Discrimination in Korean Native Chicken and Korean Native Commercial Chicken
}

\author{
Jae-Don Oh, Kun-Woo Lee, Ok-Suk Seo', Byung-Wook Cho², Gwang-Joo Jeon, Hak-Kyo Lee \\ and Hong-Sik Kong*
}

\author{
Genomic Informatics Center, Hankyong National University, Anseong 456-749, Korea \\ ${ }^{1}$ National Institute of Animal Science, Cheonan 331-801, Korea \\ ${ }^{2}$ School of Bio-Resources, Pusan National University, Busan 627-706, Korea.
}

Received April 12, 2010 /Accepted July 12, 2010

\begin{abstract}
To estimate the genetic characteristics and cumulative power of discrimination (CPD) within Korean native commercial chicken, we used a total of 395 genomic DNAs from six breeds population (Korean Native Red chicken: R, Korean Native Yellow chicken: Y, Korean native Commercial Chicken: C, Ogal chicken: S, Hy-Line Brown: H, White Leghorn: W). Genetic diversity indices including mean allele number among loci, unbiased heterozygosity $\left(\mathrm{h}_{\mathrm{i}}\right)$ within locus, effective number of alleles $\left(\mathrm{N}_{\mathrm{e}}\right)$ and polymorphism information content (PIC) as well as the unbiased average heterozygosity (H) among loci in the populations were calculated using the generated allele frequencies by each marker. Frequencies of microsatellites markers were used to estimate heterozygosities and genetic distances. The nearest distance (0.119) was observed between the $C$ and $Y$ strains. The generated unbiased average heterozygosity among loci in each population was integrated to the global formula of CPD and the result demonstrated that the CPD within the six chicken populations was $99.461 \%$.
\end{abstract}

Key words : Korean native chicken, Commercial Chicken, microsatellite markers, and cumulative power of discrimination (CPD)

\section{서 론}

최근 조류인플루엔자 발생과 광우병 등과 같이 축산물 안전 성에 대하여 국민적 관심이 어느 때보다 높아지면서 외래종 보다는 재래종의 선호도가 높아지고 있다. 또한 근래에 오면 서 국민소득과 생활수준의 향상으로 축산물 소비에 있어서도 기호에 맞고 양보다는 질을 찾는 성향이 높아지면서 재래종에 대한 선호도가 증가되고 있다. 이와 함께 토종닭에 대한 관심 이 높아지고 증가되는 수요를 위해 사육수가 크게 늘어나고 있는 추세이다. 이러한 수요증가와 함께 재래가축에 대한 유 전자원의 관심과 이를 활용한 종자산업의 중요성이 부각되었 다[13]. 이에 농촌진훙청 축산과학원은 토종닭 품종의 순수성 확립과 이를 이용한 실용화 및 산업화를 위한 연구가 추진되 게 되어 토종닭 순계(Pure Line, PL) 3계통(적갈색, 황갈색 그 리고 흑색)의 복원과 토종닭 실용계(Commercial Chicken, $\mathrm{CC}$ )을 개발하여 농가에 보급하고 있다. 또한 여러 가지 용어 로 불리는 토종닭에 대한 통일된 정의가 필요함에 따라 대표 용어로 토종닭으로 통일하기로 하였으며, 연구보고, 논문 등 학술적 용어로 원종에 대해서는 한국 재래닭(Korean native chicken)의 용어를 사용하여도 무방하도록 하였다. 그러나 토

*Corresponding author Tel : +82-31-670-5330, Fax : 82-31-675-5331

E-mail : kebinkhs@empal.com
종닭에 대한 이러한 연구와 관심에도 불구하고 국내 토종닭 산업이 자리 잡기에는 아직도 많은 문제점을 안고 있는 것이 사실이다. 토종닭으로 둔갑하여 유통되고 있는 백세미 대닭은 토종닭 유통시장을 더욱 혼탁하게 만들어 이를 타계하기 위한 여러 노력들이 진행되고 있다. 대가축의 경우 유통의 투명성 과 체계적인 혈통관리 및 질병차단을 위하여 고유숫자가 기입 된 귀표를 활용하여 개체의 식별에 이용하고 있으며 최근 전 자칩 등을 통해 개체의 고유정보를 데이터화 하여 유통과정과 연계시키는 다양한 시스템이 시도되고 있다[20]. 또한 귀표의 탈락이나 의도적인 위·변조의 가능성으로 인해 개체의 진위여 부 검증 문제를 해결하기 위해 DNA를 활용한 개체식별이 농 림수산식품부 주관으로 2007년부터 한우를 대상으로 시행되 었다[9]. 또한 돼지의 경우도 그 시행이 진행된 것은 아니지만 Microsatellite (MS) marker를 활용한 개체식별 및 원산지추적 시스템에 관한 연구가 활발히 진행되고 있는 실정이다[7,10]. MS marker는 게놈 전반에 걸쳐 분포하는 특성을 가지고 있으 며 유전적 다양성이 높아 집단 또는 개체 간 유전적 유연관계 및 다양성을 분석하는데 널리 활용되고 있다[1-3,8,11,17]. 개체 식별 및 친자확인을 위한 유전자 감식 방법으로 MS marker의 유전자형 분석은 현재 가장 보편화된 분석방법으로 채택되고 있다[6,19].

닭의 경우 소와 돼지에 비해 사육환경이나 유통과정에 많은 차이가 있어 소나 돼지에서 연구가 진행된 개체식별 및 원산 
지추적 시스템을 응용 하기에는 다소 많은 어려움이 있는 것 이 사실이다. 따라서 집단 또는 품종에 따른 유전적 특성을 구명하여 이를 이용한 원산지추적 시스템의 연구가 필요할 것으로 사료된다. 또한 토종닭의 경우 특정 순계집단에서 생 산된 종계를 활용하여 실용계를 생산하기 때문에 종계집단의 유전특성 및 유전적 구조을 활용 한다면 원산지추적 시스템 개발을 위한 접근이 가능할 것으로 사료된다. 따라서 본 연구 는 국내에서 복원된 토종닭 순계 집단과 토종닭 실용계 및 외래품종을 대상으로 MS marker의 유전다양성을 분석하여 유전적 특성을 파악하고 이를 활용한 원산지추적 시스템 개발 에 기초자료로 활용하고자 실시하였다.

\section{재료 및 방법}

\section{공시재료 및 microsatellite (MS) markers}

본 연구에서는 토종닭 순계집단(적갈계통(R) 61수, 황갈계 통(Y) 93 수), 토종닭 실용계집단(C) 75수, 오골계(OC) 70 수, 외래 품종인 Hy-Line Brown $(\mathrm{H}) 60$ 수 그리고 백색 레그혼(L) 36 수 총 395 수의 혈액에서 DNA를 분리하여 공시재료로 이용 하였고 품종별 다형성이 확인된 13종의 MS marker를 선발하 여 활용하였다. 선발된 13 종의 MS marker는 닭의 염색체상에 존재하고 있으며 Table 1에 제시하였다.

\section{유전자 증폭}

PCR 반응은 MS marker를 증폭하기 위한 primer에 형광염 색된 Dye 색상과 대립 유전자의 크기 별 분포 등을 고려하여 2 3 marker 씩 multiplex PCR을 수행하였다. PCR 반응액은 Template DNA 50 100 ng, 10× PCR Buffer $(10 \mathrm{mM}$ Tris- $\mathrm{HCl}, \mathrm{pH} 8.3,50 \mathrm{mM} \mathrm{KCl}, 1.5 \mathrm{mM} \mathrm{MgCl} 2$ ), 10 pmole of each primer, dNTPs $(2.5 \mathrm{mM})$ and 0.5 unit Taq DNA polymerase (Takara, Japan) 및 $\mathrm{ddH}_{2} \mathrm{O}$ 를 첨가하여 총량을 $10 \mu 1$ 로 맞춰 사용하였다. PCR 반응은 GeneAmp 9700 (Applied Biosystems, Foster City, CA, USA)을 사용하여 $94^{\circ} \mathrm{C}$ 에서 5 분 간 열변성 후 $94^{\circ} \mathrm{C}$ 에서 40 초, marker 별로 적정한 annealing 온도 $\left(50 \sim 60^{\circ} \mathrm{C}\right)$ 에서 1 분, $72^{\circ} \mathrm{C}$ 에서 1 분간 35 회 반응시킨 후 신장반응은 $72^{\circ} \mathrm{C}$ 에서 10 분간 수행하여 증폭된 PCR-Products 는 Ethdium Bromide를 첨가한 2\% agarose gel에서 전기영동 하여 확인하였다.

\section{MS marker의 유전자형 분석}

PCR product $1 \mu \mathrm{l}$ 를 적정 희석 배율에 따라 $\mathrm{ddH}_{2} \mathrm{O}$ 로 희석 하고, 다시 Formamide와 Genescan ${ }^{\mathrm{TM}}-500 \mathrm{LIZ}^{\mathrm{TM}}$ Size Standard 를 잘 혼합하여 희석 된 PCR product와 1:9의 비율로 혼합하 였다. 이 혼합물을 Capillary arrary가 장착된 ABI 3130 Auto Seqeuncer (Appiled Biosystems, USA)을 이용하여 유전자형

Table 1. Microsatellite marker sequences and part of PCR conditions in this study

\begin{tabular}{|c|c|c|c|c|}
\hline Marker & Chromosome & Sequence & Dye & $\operatorname{Tm}\left({ }^{\circ} \mathrm{C}\right)$ \\
\hline ADL0309 & 2 & $\begin{array}{l}\text { CCCCAGTACTGCTTCCTCAG } \\
\text { TGTGGCTGCACTTCCCAATATGT }\end{array}$ & FAM & 61 \\
\hline ADL181 & 2 & $\begin{array}{l}\text { CCAGTGAAATTCATCCTTTT } \\
\text { CAATCTTTTGTGGGGTATGG }\end{array}$ & FAM & 59 \\
\hline ADL190 & 9 & $\begin{array}{l}\text { TCAGCTCTTCAGGCAAAAAG } \\
\text { AACTTGGACCACAATCTTAT }\end{array}$ & FAM & 63 \\
\hline ADL279 & 7 & $\begin{array}{l}\text { CATGGCTGTTGCTTTACATA } \\
\text { GTGAACCCCAATGCTCTCTG }\end{array}$ & NED & 54 \\
\hline LEI0073 & 4 & $\begin{array}{l}\text { CCATATCATTTGTCAAGCACC } \\
\text { AATTCCTGACCTCCATGATAC }\end{array}$ & VIC & 65 \\
\hline LEI0192 & 6 & $\begin{array}{l}\text { TGCCAGAGCTTCAGTCTGT } \\
\text { GTCATTACTGTTATGTTTATTGC }\end{array}$ & VIC & 63 \\
\hline MCW0083 & 3 & $\begin{array}{l}\text { TACATTTCAGAAGGAATGTTGC } \\
\text { GCCTTTCACCCATCTTACTGT }\end{array}$ & VIC & 56 \\
\hline MCW0120 & 7 & $\begin{array}{l}\text { CTATGTAAAGCTTGAATCTTCA } \\
\text { ATTCCTGGGTGCTAATTTACC }\end{array}$ & VIC & 59 \\
\hline MCW0153 & 2 & $\begin{array}{l}\text { ACTGCCTGATGTAAACAAGT } \\
\text { CATATGGAAATGGCGCAGCT }\end{array}$ & FAM & 54 \\
\hline MCW214 & 5 & $\begin{array}{l}\text { CAACAGTAACCATACATCTGC } \\
\text { TACCTGGATTCTTTCATCAGG }\end{array}$ & FAM & 65 \\
\hline MCW217 & 18 & $\begin{array}{l}\text { GATCTTTCTGGAACAGATTTC } \\
\text { CTGCACTTGGTTCAGGTTCTG }\end{array}$ & NED & 63 \\
\hline MCW226 & 15 & $\begin{array}{l}\text { ACTTATCTGGCTTGCTCTCAG } \\
\text { GTCTCTCTAACCATCCTAAGC }\end{array}$ & VIC & 63 \\
\hline MCW322 & 13 & $\begin{array}{l}\text { GATCTCCCTAGCTACAAACC } \\
\text { CTTCCGCCTTCTTGAGAGTC }\end{array}$ & PET & 64 \\
\hline
\end{tabular}


분석을 실시 하였다. 분석된 유전자형은 Genmapper (Applied Biosystems, version 4.0) 프로그램을 이용하여 MS marker별 대립유전자들의 정확한 크기를 결정하였다.

\section{통계분석}

Genotyper Software에 의해 결정되어진 MS marker별 대 립유전자들은 microsatellite Toolkit software [16]를 이용하여 분석 집단별 및 개체별로 정리한 후 관측 이형질성(observed heterozygosity), 대립유전자 빈도(allele frequency), 각 locus 별 대립유전자의 수 및 집단별 대립유전자 수를 산출하였다. 각각의 분석 MS marker 좌위별 동형질성(homozygosity; $\mathrm{H}_{0}$ ), 이형질성(heterzygosity; $\mathrm{h}_{\mathrm{i}}$ )는 다음과 같이 표시된다.

$$
\mathrm{H}_{\mathrm{o}}=\sum \mathrm{P}_{\mathrm{i}}^{2}, \mathrm{~h}_{\mathrm{i}}=1-\mathrm{Ho}
$$

여기서 $\mathrm{P}_{\mathrm{i}}$ 는 MS marker의 각각의 대립유전자 빈도이다. 또 한 분석된 모든 MS marker들의 평균이형질성 $(\mathrm{H})$ 는 다음과 같이 산출하였다.

$$
\mathrm{H}=\sum \mathrm{H}_{\mathrm{j} / \mathrm{r}}
$$

여기서 $\mathrm{H}_{\mathrm{j}}$ 는 $\mathrm{j}$ 번째 MS marker의 이형질성이며 $\mathrm{r}$ 은 분석대 상 MS marker수이다. 각각의 집단에 다형성 정보량 (polymorphic information content; PIC)는 다음과 같다.

$$
\mathrm{PIC}=1-\left(\sum_{\mathrm{i}=1}^{\mathrm{k}} \mathrm{p}_{\mathrm{i}}^{2}\right)-\sum_{\mathrm{i}=1}^{\mathrm{k}-1} \sum_{\mathrm{j}=\mathrm{i}+1}^{\mathrm{k}} 2 \mathrm{p}_{1}^{2} \mathrm{p}_{\mathrm{j}}^{2}
$$

여기서 $\mathrm{P}_{\mathrm{i},} \mathrm{P}_{\mathrm{j}}$ 는 각각 $\mathrm{i}$ 번째 $\mathrm{j}$ 번째 대립유전자의 빈도이며, $\mathrm{n}$ 은 대립유전자의 개수이다. 품종 및 집단간의 유연관계 분석 을 위해 sample number의 보정을 통한 Nei 등[12]의 방법을 이용한 DISPAN program [15]을 사용하였으며, NeighborJoining(NJ) method [18]를 이용하여 genetic distances를 추정 하여 이를 근거로 한 phylogenetic tree를 작성하였다. 또한 집단간 누적 식별력(Cumulative power of discrimination; $\mathrm{CPD}$ )는 Fan 등[4]이 제시한 바에 따라 다음과 같이 산출하였다.

$$
\mathrm{CPD}=\left(1-\left[\left(1-\mathrm{H}_{\mathrm{a}}\right)\left(1-\mathrm{H}_{\mathrm{b}}\right)\left(1-\mathrm{H}_{\mathrm{c}}\right)\left(1-\mathrm{H}_{\mathrm{d}}\right)\left(1-\mathrm{H}_{\mathrm{e}}\right)\left(1-\mathrm{H}_{\mathrm{f}}\right]\right)\right) \times 100 \%
$$

여기서 $\mathrm{H}_{\mathrm{a}} \sim \mathrm{H}_{\mathrm{f}}$ 는 각각 분석대상 집단 별 전체 분석된 MS marker의 평균 이형질성이다.

\section{결과 및 고찰}

본 연구는 토종닭 순계(적갈계통: $\mathrm{R}$, 황갈계통: $\mathrm{Y})$, 토종닭 실용계 $(\mathrm{C})$ 와 오골계 $(\mathrm{O})$ 및 외래품종(Hy-Line Brown: $\mathrm{H}$, White Leghorn: W)을 대상으로 13종의 MS marker을 활용하 여 집단 및 품종간의 유전적 다양성을 분석하였다. 공시재료 를 대상으로 각각의 MS marker의 유전자형을 분석하여 전체 집단의 PIC (polymorphism information content: PIC)와 관측 된 이형질성(Observed Heterozygosity: $\mathrm{Ob} \mathrm{H}$ ) 및 기대되는
이형질성(Expected Heterozygosity: Ex H)를 계산하여 Table 2에 제시하였다. 결과에 따르면 분석된 MS marker들은 보유 한 대립유전자의 수가 3-20개로 다양하게 보유하고 있음을 확 인하였다. 13 종의 MS marker내에서 총 120 개의 대립유전자를 확인하였으며 평균 9.2개의 대립유전자를 보유한 것으로 나타 났다. 그러나 ADL0309의 경우 3개의 대립유전자를 보유한 것 으로 나타나 전체 MS marker중 가장 적은 수의 대립유전자를 보유한 반면 비교적 높은 이형질성(0.655)을 나타냈으며, LEI0192의 경우 가장 많은 20개의 대립유전자를 보유한 것으 로 확인되었다. 관측된 이형질성의 경우 전체평균은 0.63 으로 계산되었으며 ADL279는 가장 낮은 이형질성을 가진 것으로 나타났는데 반면 PIC의 값은 0.726 으로 상당히 높은 것으로 확인되었다. 이는 보유한 12 개의 대립유전자들의 유전자형 이 형접합체의 수는 적어도 다양한 동형접합체들이 존재하고 있 어 기인한 현상으로 확인되었다. 또한 ADL190은 0.754 의 가장 높은 관측된 이형 질성을 나타냈으며 8 개의 대립유전자를 보 유하고 있는 것으로 확인되었다. 기대되는 이형질성과 PIC의 평균값은 각각 0.72 와 0.678 로 확인되었다. MCW 322 는 4 개의 대립유전자를 보유하고 있으며 관측된 이형질성과 PIC 모두 에서 가장 낮은 수치가 확인되었다(각각 $0.491,0.533$ ). 반면 MCW120은 12 개의 대립유전자를 보유하고 있으며 가장 높은 관측된 이형 질성과 PIC 값(각각 0.713 와 0.84 )을 나타내고 있 었다.

Table 3은 각 집단 및 품종에 대한 13종의 MS marker의 유전자형을 분석하여 보유한 평균대립유전자수와 관측된 이 형질성 $(\mathrm{Ob} \mathrm{H})$ 및 기대되는 이형질성 $(\mathrm{Ex} \mathrm{H})$ 의 평균값을 제시 하였다. 분석결과 가장 많은 평균대립유전자를 보유한 집단은 토종닭 실용계 집단이 5.9 로 확인 되었으며 기대되는 이형질 성이 0.629 로 비교적 높게 나타났다. 이는 토종닭 순계집단을

Table 2. Characterization of the 13 microsatellite loci analyzed in 6 popuations

\begin{tabular}{ccccc}
\hline Loci & No. of alleles & PIC & Ob H & Ex H \\
\hline ADL0309 & 3 & 0.586 & 0.655 & 0.659 \\
ADL181 & 5 & 0.567 & 0.602 & 0.636 \\
ADL190 & 8 & 0.718 & 0.754 & 0.759 \\
ADL279 & 12 & 0.726 & 0.384 & 0.760 \\
LEI0073 & 17 & 0.735 & 0.665 & 0.756 \\
LEI0192 & 20 & 0.753 & 0.630 & 0.769 \\
MCW0083 & 5 & 0.716 & 0.696 & 0.754 \\
MCW0120 & 12 & 0.840 & 0.713 & 0.856 \\
MCW0153 & 4 & 0.594 & 0.663 & 0.660 \\
MCW214 & 11 & 0.748 & 0.693 & 0.776 \\
MCW217 & 8 & 0.720 & 0.653 & 0.755 \\
MCW226 & 11 & 0.573 & 0.587 & 0.637 \\
MCW322 & 4 & 0.533 & 0.491 & 0.585 \\
\hline All loci & 120 & 0.678 & 0.630 & 0.720 \\
\hline
\end{tabular}

PIC: Polymorphism information content, $\mathrm{Ob} \mathrm{H}$ : observed heterozygosity, Ex H: expected heterozygosity. 
Table 3. Expected, observed heterozygosity and mean number of alleles (MNA) observed across 13 microsatellite loci for each population

\begin{tabular}{ccccc}
\hline \multirow{2}{*}{ Populations } & Sample size & MNA & Ex H & Ob H \\
\hline R & 61 & 4.8 & 0.601 & 0.571 \\
Y & 93 & 5 & 0.630 & 0.574 \\
C & 75 & 5.9 & 0.629 & 0.564 \\
O & 70 & 4.3 & 0.546 & 0.531 \\
H & 60 & 4 & 0.567 & 0.600 \\
W & 36 & 4.4 & 0.490 & 0.409 \\
\hline
\end{tabular}

R: Korea native Red chicken, Y: Korea native Yellow chicken, $\mathrm{C}$ : Korea native Commercial chicken, $\mathrm{O}$ : Ogol chicken, $\mathrm{H}$ : Hy-Line Brown, W: White Leghorn, MNA: mean number of alleles, $\mathrm{Ob} \mathrm{H}$ : mean observed heterozygosity, Ex $\mathrm{H}$ : mean expected heterozygosity.

이용한 3원 교잡을 통해 실용계집단을 생산하는 과정에서 기 인한 것으로 추정된다. 관측된 이형질성의 경우는 하이라인 브라운종 $(\mathrm{H})$ 에서 0.6 으로 가장 높은 것으로 확인되었다. 반면 화이트레그혼종 $(\mathrm{L})$ 의 경우 관측된 이형질성이 0.409 로 가장 낮게 나타났다. 같은 외래 품종간 이들의 차이는 국내에 최초 수입되어 계대를 유지해 오면서 국내에서 토착화 과정을 거친 토착화 품종인 화이트 레그혼종과 매년 12천수의 원종계를 수입하여 종계를 생산하여 농가에 보급이 되고 있는 하이라인 브라운종(http://www.Poultryegg.co.kr)간의 사육 환경 및 목적이 반영된 유전적 특성의 차이에서 기인한 것으로 추정 된다.

6개의 집단 및 품종간의 유전적 유연관계를 알아보기 위해 각 MS marker별 대립유전자의 빈도를 산출하여 이를 근거로 집단간의 보정을 통한 $\mathrm{Nei}$ 등[12]의 방법을 이용하는 DISPAN program을 활용하여 유전적 거리에 대한 추정하여 Table 4에
제시하였다. 분석된 결과에 따르면 토종닭 실용계집단(C)의 경우 토종닭 순계 황갈계통집단(Y)과의 유전적 거리가 0.119 로 가장 가깝게 나타났으며 토종닭 순계 적갈계통집단(R)과도 0.126 으로 매우 가까운 것으로 확인 되어 토종닭 순계집단(R 과 $\mathrm{Y})$ 과 실용계집단(C)은 서로간에 가까운 유전적 거리를 유 지하고 있는 것으로 확인되었다. 하이라인 브라운 $(\mathrm{H})$ 은 C집단 과의 유전적 거리가 0.170 으로 확인되어 화이트 레그혼종 $(\mathrm{W})$ 과 C집단간의 0.186 보다 가까운 것으로 확인 되었다. 이렇게 분석된 genetic matrix (Table 4)를 근거로 하여 NJ (NeighborJoining [18]의 clustering 방법을 이용하여 Fig. 1에 집단 간의 유전적 거리에 대한 분지도를 작성하여 제시하였다.

Table 5는 각 집단 및 품종 별 각각의 MS marker에 대한 유전자형을 분석하여 보유한 대립유전자수와 이형질성 $\left(\mathrm{h}_{\mathrm{i}}\right)$ 그 리고 PIC값을 제시하였고, 각 MS marker별 품종간의 이형접 합률을 이용하여 각 개체들의 집단 내에서 품종을 식별 할 수 있는 확률인 누적품종식별력(CPD)값을 계산한 결과 분석 된 13종의 MS marker를 이용하여 개체의 품종을 구분할 수 있는 확률이 $99.461 \%$ 로 나타났다. 이는 재래돼지 집단에서 10 종의 MS marker를 활용할 경우 최고 $96.40 \%$ 까지 누적 품종 식별력을 보인다는 결과를 제시한 Fan 등[5]의 결과보다 다소 높은 수치를 보였으며, 가금 집단 내에 9 11종의 MS marker 를 통한 누적품종식별력이 98.75[14]로 나타낸 것과 비교하여 다소 높게 추정되었다. 또한 국내의 한우집단과 육우집단을 대상으로 16 종의 MS marker를 활용하여 $99.06 \%$ 의 누적품종 식별력을 확인한 김 등[7]의 결과 보다 다소 높은 것으로 확인 되었다. 이는 분석에 활용된 토종닭 순계의 경우 긴 시간에 걸쳐 순수화 복원 사업을 통해 그 유전적 특성이 고정화되었 으며 이러한 순계집단을 이용하여 토종닭 실용계집단을 생산 하였기 때문에 다른 품종들과의 유전적 차별성이 나타난 것에

Table 4. DA genetic distance matrix estimated from the frequencies of 13 microsatellite loci among the 6 populations of chicken

\begin{tabular}{ccccccc}
\hline & $\mathrm{R}$ & $\mathrm{Y}$ & $\mathrm{C}$ & $\mathrm{O}$ & $\mathrm{H}$ & $\mathrm{W}$ \\
\hline $\mathrm{R}$ & - & & & & \\
$\mathrm{Y}$ & 0.1375 & - & & & \\
$\mathrm{C}$ & 0.1266 & 0.1191 & - & & \\
$\mathrm{O}$ & 0.2076 & 0.1912 & 0.1741 & - & - \\
$\mathrm{H}$ & 0.1791 & 0.2066 & 0.1707 & 0.1990 & 0.2665 \\
W & 0.2440 & 0.2395 & 0.1869 & 0.1748 & - \\
\hline
\end{tabular}

R: Korea native Red chicken, Y: Korea native Yellow chicken, C: Korea native Commercial chicken, O: Ogol chicken, H: Hy-Line Brown, W: White Leghorn.

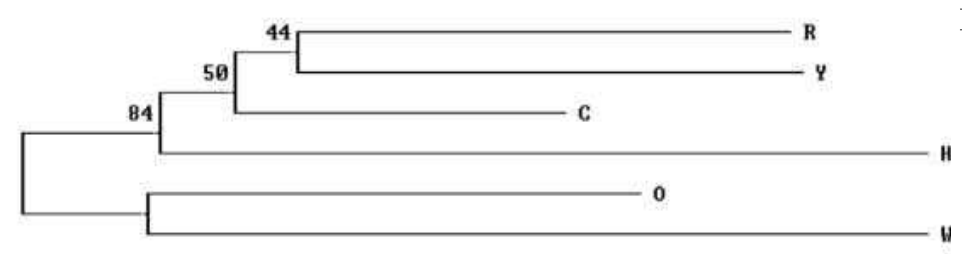

Fig. 1. Phylogenetic tree showing the genetic relations among 6 population based on DA genetic distance [12]. The numbers indicate bootstrap values in percentage after 1,000 re-sampling. R: Korea native Red chicken, Y: Korea native Yellow chicken, $\mathrm{C}$ : Korea native Commercial chicken, O: Ogol chicken, H: Hy-Line Brown, W: White Leghorn. 
Table 5. Characterization of genetic variability and cumulation power of breeds discrimination (CPD)

\begin{tabular}{|c|c|c|c|c|c|c|c|c|}
\hline \multirow{2}{*}{ Locus } & \multirow{2}{*}{ Observed features } & \multicolumn{6}{|c|}{ Breeds(strain) } & \multirow{2}{*}{$\begin{array}{c}\text { Cross breeds } \\
\text { mean }\end{array}$} \\
\hline & & $\mathrm{R}$ & $\mathrm{Y}$ & $\mathrm{C}$ & $\mathrm{O}$ & $\mathrm{H}$ & W & \\
\hline \multirow{3}{*}{ ADL0309 } & Allele number & 3 & 3 & 3 & 3 & 3 & 3 & 3.000 \\
\hline & $\mathrm{h}_{\mathrm{i}}$ & 0.574 & 0.677 & 0.653 & 0.771 & 0.617 & 0.583 & 0.650 \\
\hline & PIC & 0.528 & 0.588 & 0.534 & 0.584 & 0.491 & 0.507 & 0.540 \\
\hline \multirow{3}{*}{ ADL181 } & Allele number & 4 & 3 & 4 & 2 & 3 & 4 & 3.330 \\
\hline & $\mathrm{h}_{\mathrm{i}}$ & 0.754 & 0.645 & 0.667 & 0.329 & 0.600 & 0.639 & 0.610 \\
\hline & PIC & 0.590 & 0.571 & 0.569 & 0.295 & 0.522 & 0.546 & 0.520 \\
\hline \multirow{3}{*}{ ADL190 } & Allele number & 5 & 5 & 6 & 5 & 4 & 5 & 5.000 \\
\hline & $\mathrm{h}_{\mathrm{i}}$ & 0.754 & 0.677 & 0.867 & 0.786 & 0.867 & 0.472 & 0.740 \\
\hline & PIC & 0.630 & 0.660 & 0.685 & 0.762 & 0.620 & 0.502 & 0.640 \\
\hline \multirow{3}{*}{ ADL279 } & Allele number & 6 & 6 & 10 & 7 & 4 & 7 & 6.670 \\
\hline & $\mathrm{h}_{\mathrm{i}}$ & 0.508 & 0.473 & 0.360 & 0.200 & 0.233 & 0.611 & 0.400 \\
\hline & PIC & 0.707 & 0.668 & 0.763 & 0.639 & 0.556 & 0.678 & 0.670 \\
\hline \multirow{3}{*}{ LEI0073 } & Allele number & 7 & 5 & 11 & 6 & 6 & 8 & 7.170 \\
\hline & $\mathrm{h}_{\mathrm{i}}$ & 0.590 & 0.613 & 0.733 & 0.714 & 0.650 & 0.722 & 0.670 \\
\hline & PIC & 0.550 & 0.571 & 0.774 & 0.624 & 0.465 & 0.719 & 0.620 \\
\hline \multirow{3}{*}{ LEI0192 } & Allele number & 8 & 7 & 12 & 5 & 9 & 3 & 7.330 \\
\hline & $\mathrm{h}_{\mathrm{i}}$ & 0.689 & 0.527 & 0.600 & 0.729 & 0.883 & 0.250 & 0.610 \\
\hline & PIC & 0.743 & 0.720 & 0.694 & 0.597 & 0.720 & 0.319 & 0.630 \\
\hline \multirow{3}{*}{ MCW0083 } & Allele number & 5 & 5 & 5 & 4 & 3 & 4 & 4.330 \\
\hline & $\mathrm{h}_{\mathrm{i}}$ & 0.820 & 0.710 & 0.720 & 0.743 & 0.800 & 0.139 & 0.660 \\
\hline & PIC & 0.688 & 0.597 & 0.643 & 0.625 & 0.586 & 0.236 & 0.560 \\
\hline \multirow{3}{*}{ MCW0120 } & Allele number & 7 & 7 & 10 & 8 & 4 & 5 & 6.830 \\
\hline & $\mathrm{h}_{\mathrm{i}}$ & 0.705 & 0.581 & 0.840 & 0.829 & 0.783 & 0.472 & 0.700 \\
\hline & PIC & 0.710 & 0.649 & 0.815 & 0.777 & 0.599 & 0.470 & 0.670 \\
\hline \multirow{3}{*}{ MCW0153 } & Allele number & 4 & 4 & 4 & 3 & 3 & 2 & 3.330 \\
\hline & $\mathrm{h}_{\mathrm{i}}$ & 0.623 & 0.763 & 0.760 & 0.671 & 0.483 & 0.556 & 0.640 \\
\hline & PIC & 0.612 & 0.605 & 0.597 & 0.486 & 0.383 & 0.368 & 0.510 \\
\hline \multirow{3}{*}{ MCW214 } & Allele number & 7 & 8 & 7 & 6 & 5 & 8 & 6.830 \\
\hline & $\mathrm{h}_{\mathrm{i}}$ & 0.590 & 0.753 & 0.587 & 0.729 & 0.883 & 0.555 & 0.680 \\
\hline & PIC & 0.491 & 0.739 & 0.587 & 0.728 & 0.753 & 0.590 & 0.650 \\
\hline \multirow{3}{*}{ MCW217 } & Allele number & 5 & 5 & 6 & 6 & 5 & 7 & 5.670 \\
\hline & $\mathrm{h}_{\mathrm{i}}$ & 0.656 & 0.807 & 0.520 & 0.786 & 0.617 & 0.333 & 0.620 \\
\hline & PIC & 0.619 & 0.699 & 0.602 & 0.680 & 0.512 & 0.512 & 0.600 \\
\hline \multirow{3}{*}{ MCW226 } & Allele number & 4 & 10 & 4 & 5 & 4 & 5 & 5.330 \\
\hline & $\mathrm{h}_{\mathrm{i}}$ & 0.443 & 0.688 & 0.373 & 0.643 & 0.950 & 0.306 & 0.570 \\
\hline & PIC & 0.369 & 0.604 & 0.492 & 0.486 & 0.581 & 0.614 & 0.520 \\
\hline \multirow{3}{*}{ MCW322 } & Allele number & 4 & 3 & 3 & 2 & 4 & 2 & 3.000 \\
\hline & $\mathrm{h}_{\mathrm{i}}$ & 0.689 & 0.591 & 0.573 & 0.043 & 0.583 & 0.444 & 0.490 \\
\hline & PIC & 0.565 & 0.569 & 0.422 & 0.041 & 0.475 & 0.334 & 0.400 \\
\hline \multirow{3}{*}{ Among loci mean } & Allele number & 5.308 & 5.462 & 6.538 & 4.769 & 4.385 & 4.846 & 2.500 \\
\hline & $\mathrm{h}_{\mathrm{i}}$ & 0.646 & 0.654 & 0.635 & 0.613 & 0.688 & 0.468 & 0.100 \\
\hline & PIC & 0.600 & 0.634 & 0.629 & 0.563 & 0.558 & 0.492 & 0.310 \\
\hline
\end{tabular}

R: Korea native Red chicken, Y: Korea native Yellow chicken, C: Korea native Commercial chicken, O: Ogol chicken, H: Hy-Line Brown, W: White Leghorn. PIC: Polymorphism information content, $\mathrm{h}_{\mathrm{i}}$ : heterozygosity, CPD: cumulative power of discrimination.

기인하는 것으로 추정된다. 토종닭 실용계집단의 경우 보유하 고 있는 평균 대립유전자의 수가 다른 집단 또는 품종들에 비해 다양한 것으로 확인 되었으며 이 역시 3원 교배를 통해 실용계를 생산한 것에 기인하는 것으로 사료된다. 따라서 토
종닭의 진위 여부를 판별하기 위해 본 연구결과에서 제시한 13 종의 MS marker를 활용 할 경우 누적품종식별확률은 $99.461 \%$ 로 확인되었으며 차후 국내 토종닭 산업에 활용하기 위해서는 시중에 유통되고 있는 더 많은 품종들을 대상으로 
연구를 진행하여 그 오차 범위를 최대한 줄일 수 있도록 하는 것이 무엇보다 중요할 것으로 사료되어 진다.

\section{감사의 글}

본 연구는 경기도의 경기도지역협력연구센터(GRRC) 사업 의 일환으로 수행하였음[GRRC한경2010-B03, 동물유전 및 천 연물 소재를 이용한 안전 축산물 가공기술 개발].

\section{References}

1. Barker, J. S. F., S. G. Tan, O. S. Selvaraj, and T. K. Mukherjee. 1997. Genetic variation within and relationships among populations of Asian water buffalo (Bubalus bubalis). Anim Genet. 28, 1-13.

2. Bjornstad, G., N. O. Nilsen, and K. H. Roed. 2003. Genetic relationship between Mongolian and Norwegian horses. Anim Genet. 34, 55-58.

3. Buchanan, F. C., L. J. Adams, R. P. Littlejohn, J. F. Maddox, and A. M. Crawford. 1994. Determination of evolutionary relationships among sheep breeds using microsatellites. Genomics 22, 397-493.

4. Fan, B., Z. G. Wang, Y. J. Li, X. L. Zhao, B. Liu, S. H. Zhao, M. YU, M. H. Li, S. L. Chen, T. A. Xiong, and K. Li. 2002. Genetic variation analysis within and among Chinese indigenous swine populations using microsatellite markers. Anim Genet. 33, 422-427.

5. Fan, B., Y. Chen, C. Moran, S. Zhao, B. Liu, M. Zhu, T. Xiong, and K. Li. 2005. Individual-breed assignment analysis in swine populations by using microsatellite markers. Asian-Aust. J. Anim Sci. 18, 1529-1534.

6. Fries, R. and G. Durstewitz. 2001. Digital DNA signatures: SNPs for animal tagging. Nat. Biotechnol. 19, 508.

7. Kim, S. W., H. K. Jang, K. S. Kim, J. J. Kim, J. T. Jeon, D. H. Yoon, S. H. Kang, H. I. Jung, and I. C. Cheong. 2009. Establishment of genetic characteristics and individual identification system using microsatellite loci in domestic beef cattle. J. Anim Sci. Technol. 51, 273-282.

8. Li, K., Y. Chen, C. Moran, B. Fan, S. Zhao, and Z. Peng. 2000. Analysis of diversity and genetic relationships be- tween four Chinese indigenous pig breeds and one Australian commercial pig breed. Anim Genet. 31, 322-325.

9. Lim, H. T., H. S. Min, W. G. Moon, J. B. Lee, J. H. Kim, I. C. Cho, and H. K. Lee. 2005. Analysis and selection of microsatellites markers for individual traceability system in Hanwoo. J. Anim Sci. Technol. 47, 491-500.

10. Lim, H. T., B. Y. Seo, E. J. Jung, C. K. Yoo, T. Zhong, I. C. Cho, D. H. Yoon, J. G. Lee, and J. T. Jeon. 2009. Establishment of a microsatellite marker set for individual, pork brand and product origin identification in pigs. $J$. Anim Sci. Technol. 51, 201-206.

11. Martin-Burriel, I., E. Garcia-Muro, and P. Zaragoza. 1999. Genetic diversity analysis of six Spanish native cattle breeds using microsatellites. Anim Genet. 30, 177-182.

12. Nei, M., F. Tajima, and Y. Tateno. 1983. Accuracy of estimated phylogenetic trees from molecular data. J. Mol. Evol. 19, 153-170.

13. Notter, D. R. 1999. The Importance of genetic diversity in livestock populations of the future. J. Anim Sci. 77, 61-69.

14. Olowofeso, O., Y. Wang, J. Shen, K. Chen, H. Sheng, P. Zhang, and R. Wu. 2005. Estimation of the cumulative power of discrimination in Haimen chicken populations withen microsatellite markers. Asian-Aust. J. Anim Sci. 18, 10661070.

15. Ota, T. 1993. DISPAN. Pennsylvania State University, PA. USA.

16. Park, S. D. E. 2000. Microsatellite Toolkit for MS Excel 97 or 2000. (in personnel communication).

17. Peelman, L. J., F. Mortiaux, A. Van Zeveren, A. Dansercoer, G. Mommens, F. Coopman, Y. Bouquet, A. Burny, R. Renaville, and D. Portetelle. 1998. Evaluation of the genetic variability of 23 bovine microsatellite markers in four Belgian cattle breeds. Anim Genet. 29, 161-167.

18. Saitou, N. and M. Nei. 1987. The neighbor-joining method: A new method for reconstructing phylogenetic tree. Mol. Biol. Evol. 4, 406-425.

19. Sancrostoval, M., G. Renald, and Y. Amigues. 2000. Tracabilite individuelle des viandes bovinew a l'aide de marqueurse genetiques. INRA. Prod Anim 13, 269-276.

20. Seo, K. S., Y. M. Cho, and H. K. Lee. 2000. Development of network system for the application of HACCP in livestock production stage. J. Agroinformatics 1, 1-4. 


\section{초록 : 토종닭 순계와 실용계의 유전적 특성 및 품종식별력 분석}

오재돈 · 이건우 · 서옥석 ${ }^{1}$ - 조병욱 · 전광주 · 이학교 · 공홍식*

(한경대학교 유전정보연구소, ${ }^{1}$ 축산과학원, ${ }^{2}$ 부산대학교 생명자원과학대학)

본 연구는 토종닭 순계(적갈계통, 황갈계통), 토종닭 실용계와 오골계 및 외래품종(Hy-Line Brown: HB, White Leghorn: WL)을 대상으로 13종의 MS marker (ADL0309, ADL181, ADL190, ADL279, LEI0073, LEI0192, MCW083, MCW120, MCW153, MCW214, MCW217, MCW226, MCW322)을 활용하여 집단 및 품종간의 유전적 다양성을 분석 하였다. 13 종의 MS marker 내에서 총 120 개의 대립유전자를 확인 하였으며 평균 9.2 개의 대립유 전자를 보유한 것으로 나타났다. 관측된 이형질성, 기대되는 이형질성 및 PIC의 평균값은 각각 $0.63,0.72$ 그리고 0.678 로 확인되었다. 가장 많은 평균대립유전자를 보유한 집단은 토종닭 실용계집단이 5.9 로 확인 되었으며 기대 되는 이형질성이 0.629 로 비교적 높게 나타났다. 이는 토종닭 순계 집단을 이용한 3원 교잡을 통해 실용계집단을 생산하는 과정에서 기인한 것으로 추정된다. 집단 및 품종간의 유전적 유연관계를 분석한 결과 토종닭 순계집단 $(\mathrm{R}, \mathrm{Y})$ 과 실용계집단(C)은 서로간에 가까운 유전적 거리를 유지하고 있는 것으로 확인되었다. 각 MS marker별 품종간의 이형접합률을 이용하여 각 개체들의 집단 내에서 품종을 식별 할 수 있는 확률인 누적품종식별력(CPD) 값을 계산한 결과 13 종의 MS marker를 이용하여 개체의 품종을 구분할 수 있는 확률이 $99.461 \%$ 로 나타났다. 